\title{
Масштаб личности
}

DOI: $10.30727 / 0235-1188-2019-62-2-158-159$

Personalia

Вячеслав Семенович Степин... О нем будут писать и как об ученом (мыслителе, философе, методологе естествознания), и как об организаторе науки, и как об учителе, и как о человеке... И главное, что всегда будет выходить на передний план, - это то, что во всех своих проявлениях он был удивительно цельным и удивительно масштабным.

Масштаб личности: ученый - великий, организатор науки выдающийся, учитель - от Бога, Человек - с большой буквы. За что бы он ни брался, что бы он ни делал, - все получалось полновесно значительным и универсально значимым. Вся его жизнь - от начала и, увы, до свершившегося конца - цельное и целостное явление, изменяемое категориями мирового масштаба.

Он сформировался и реализовал себя как философ в Беларуси, в полной мере проявил себя как организатор науки в России. Это так, но измерять значимость его свершений можно и должно сугубо в контексте мировой историко-философской традиции. В.С. Степин - философ, действительно, мирового масштаба: его концепция развития научной теории вошла в золотой фонд всемирной философии, и современная методология немыслима без таких имен, как Т. Кун, К. Поппер, В.С. Степин.

Его организаторские способности - где бы он ни работал: в Минске ли, в Москве ли, - заставляли пространство вокруг него кипеть энтузиазмом творческого поиска, формировали научную среду высокой степени креативности.

Это проявилось и в формировании Минской методологической школы, и в работе академического Института истории естествознания и техники в Москве, и в радикальной трансформации Института философии РАН, его переходе к демократическим принципам руководства наукой, и в работе Российского философского общества, и в реализации плодотворных международных взаимодействий в сфере научных исследований.

Наука - явление, развивающееся вне узких рамок национальных границ, и академик В.С. Степин всегда был тем центром, к которому тянулись и вокруг которого сплетались наиболее актуальные векторы научного поиска. И он обладал удивительной способностью создавать на этой основе конкретные и воистину масштабные исследовательские проекты, осуществление которых приводило к реальным научным результатам, существенно продвигающим вперед современную философию.

Это всегда было так, хотя его работа - и в Минске, и отчасти в Москве - пришлась на непростой исторический отрезок в развитии науки: это и время советской идеологизации научных исследований, когда были существенно затруднены не только международные науч- 
ные контакты, но и доступ к современной зарубежной литературе, и перестроечный период, связанный с финансовыми проблемами реализации научных проектов. Однако, как бы ни складывались внешние обстоятельства, B.С. Степин всегда находил возможность не только самому быть на острие мирового научного поиска, но и вести за собой других: он умел ставить именно те проблемы, через решение которых пролегали магистральные пути развития современной философии; он умел создавать такие проекты, которые всегда находили поддержку; он всегда умел вдохновлять окружающих его ученых на самоотверженный научный поиск.

И если говорить о Вячеславе Семеновиче как об учителе, то он оставил после себя не просто учеников - он создал когорту единомышленников, которые продолжают его дело, развивая заложенные им традиции - традиции как содержательные, касающиеся развития намеченных им научных направлений и поставленных им философскометодологических проблем, так и традиции нравственные, фундирующие внутринаучные коммуникации принципами высокой морали.

Всё это осталось. Осталось как научное наследие академика B.C. Степина, причем наследие живое, развивающееся и прирастающее достижениями его соратников и учеников.

Но сколь же многое ушло, ушло невозвратно, оставив после себя боль в наших сердцах...

Не будет больше его новых публикаций, каждая из которых задавала новое видение казалось бы вечных философских проблем, инспирируя на новые исследования и новые раздумья, чреватые новыми научными открытиями...

Не будет больше его блистательных докладов, после которых ход конференций неизменно вспыхивал новыми красками, новыми мыслями, проблемами, дебатами, направлениями...

Не будет больше ярких лекций, когда завораживающие слушателей неожиданные повороты мысли озаряла его улыбка, которой он сам не замечал, - улыбка радости от гармонии той онтологической подоплеки, которая лежала в основании разворачивающейся логической цепочки...

Не будет больше байдарочных походов по Минскому морю, когда вечера у костра так легко и незаметно переходили от авторской песни под гитару к философским дискуссиям на всю ночь...

Не будет... Не будет...

И не пополниться более когорта его учеников...

Или пополнится? Ведь остались книги, остались единомышленники и соратники, остались ученики его учеников и осталась мировая философская традиция, в которую имя академика В.С. Степина вписано теперь навсегда.

М.А. МОЖЕЙКО, заведуюшая кафедрой философии и методологии гуманитарных наук Белорусского государственного университета культуры и искусств, доктор философских наук, профессор 